\title{
A review of antimalarial plants used in traditional medicine in communities in Portuguese-Speaking countries: Brazil, Mozambique, Cape Verde, Guinea-Bissau, São Tomé and Príncipe and Angola
}

\author{
Jefferson Rocha de A Silva', Aline de S Ramos², Marta Machado³, Dominique F de Moura', \\ Zoraima Neto ${ }^{3}$, Marilene M Canto-Cavalheiro ${ }^{4}$, Paula Figueiredo 3 , \\ Virgilio E do Rosário ${ }^{3}$, Ana Claudia F Amaral'², Dinora Lopes ${ }^{3 /+}$
}

\begin{abstract}
'Laboratório de Cromatografia, Departamento de Química, Universidade Federal do Amazonas, Manaus, AM, Brasil ${ }^{2}$ Laboratório de Plantas Medicinais e Derivados, Departamento de Produtos Naturais, Farmanguinhos ${ }^{4}$ Instituto Oswaldo Cruz-Fiocruz, Rio de Janeiro, RJ, Brasil ${ }^{3}$ Unidade de Parasitologia, Instituto de Higiene e Medicina Tropical, Universidade Nova de Lisboa, Lisboa, Portugal

The isolation of bioactive compounds from medicinal plants, based on traditional use or ethnomedical data, is a highly promising potential approach for identifying new and effective antimalarial drug candidates. The purpose of this review was to create a compilation of the phytochemical studies on medicinal plants used to treat malaria in traditional medicine from the Community of Portuguese-Speaking Countries (CPSC): Angola, Brazil, Cape Verde, Guinea-Bissau, Mozambique and São Tomé and Principe. In addition, this review aimed to show that there are several medicinal plants popularly used in these countries for which few scientific studies are available. The primary approach compared the antimalarial activity of native species used in each country with its extracts, fractions and isolated substances. In this context, data shown here could be a tool to help researchers from these regions establish a scientific and technical network on the subject for the CPSC where malaria is a public health problem.
\end{abstract}

Key words: antimalarial - medicinal plants - extracts - malaria - folk medicine

Malaria is a serious parasitic disease from tropical regions caused by a species of Plasmodium and transmitted by Anopheles mosquitoes. It is prevalent in approximately 100 countries in Africa, Southeast Asia and South America, where approximately 2.4 million people are at risk (Kager 2002). According to the World Malaria Report (WHO 2009a), there are approximately 250 million malaria cases and approximately one million people die from malaria each year.

The emergence and rapid spread of multidrug-resistant strains of Plasmodium, particularly Plasmodium falciparum, represent a major problem for prophylaxis and treatment, which becomes more difficult and limits the choice of drugs used. This has been identified as the current primary cause of control failure.

The well-known use of chloroquine (CQ) and antifolates [sulfadoxine-pyrimethamine $(\mathrm{S} / \mathrm{P})$ ] for malaria treatment are no longer effective in most endemic areas. Combination therapy has emerged as the best practical solution in overcoming the resistance of select strains. Therapeutics based on combinations with artemisinin and derivatives (ACTs), recommended by the World Health Organization (WHO), presently represent the most effective treatment of $P$. falciparum malaria infec-

Financial support: RIDES Malaria CPLP, CNPq, FAPEAM (to DFM) (PPP and PIPT projects), IFS (Sweden) (AF/18880), OPCW (Netherlands), CAPES-FCT (to JRAS and VER) (project 204/08)

+ Corresponding author: dferreira@ihmt.unl.pt

Received 25 March 2011

Accepted 26 July 2011 tion (WHO 2008). Clinical resistance to these combinations has been recently reported in Cambodia (Noedl et al. 2008), suggesting that P. falciparum parasites have already developed the ability to grow in the presence of these antimalarials, which strongly suggests the need for further research into new antimalarials.

There is broad consensus on the urgent need for new, affordable and efficient compounds that could serve as primary molecules for antimalarial treatment. New highly-effective antimalarial drug candidates, based on new mechanisms of action or with new structures, are urgently needed to overcome the problem of rapid emergence of drug resistance and achieve long-term clinical efficacy.

Due to the crucial role that plant-derived compounds have played in drug discovery and development for the treatment of several diseases, the isolation of new bioactive compounds from medicinal plants based on traditional use or ethnomedical data appears to be a very promising approach (Newman 2008, Turschner \& Efferth 2009).

There is a consensus among the scientific community that natural products have a dominant presence in discovering new leads for the development of drug treatment for human diseases. In fact, of the 877 novel medicines that were developed in the period between $1981-2002,6 \%$ were natural products, $27 \%$ were derivatives of natural products and $16 \%$ were synthetics developed based on a natural product (Newman et al. 2003). At least $80 \%$ of the world population is estimated to be continuing use of such traditional medicines in primary health care, including 40,000-70,000 medicinal plants, approximately $20 \%$ of all higher-plant species (Verpoorte et al. 2006). In most cases, very little is known about the plants used in folk medicines. 
In malaria therapy, 11 drugs out of the antimalarials included in WHO therapeutic schemes for malaria treatment are natural products or their analogues or were design-based on the pharmacophores from natural products (Bourdy et al. 2008). The great significance of plant-derived drugs for the treatment of the disease is highlighted by quinine (derived from Cinchona tree), artemisinin (derived from Artemisia annua) and atovaquone (Malarone $\left.{ }^{\circledR}\right)$, which is a synthetic compound (2-alkyl-3-hydroxynaphthoquinone) analogue of lapachol from the Tabebuia species (Bignoniaceae) (Oliveira et al. 2009).

This review was based on compilation of medicinal plants used in traditional medicine in the treatment of malaria infections in some countries of the Community of Portuguese-Speaking Countries (CPSC), which includes Angola, Brazil, Cape Verde, Guinea-Bissau, Mozambique and São Tomé and Príncipe (STP) and involved the comparison of popularly used native species and studies on the antimalarial activity of extracts, fractions and isolated substances.

The areas included in the CPSC are, to different degrees, developing nations where large fragments of the population have limited access to the National Health System. Consequently, these segments of the population use traditional medicine and their by products for therapy. This pattern is clearly observed in Africa. There is a large body of literature from studies in Africa, but they are from different time periods and, in some cases, references to malaria may be read as anti-fever. Due to the differences in methods, models or assays used, not all of the information is comparable. This review is intended to be useful for establishing networks aimed at training, data comparison, standardisation of techniques, incorporation of ethical issues into research and development activities and development of a website for the CPSC.

In this context, a selection of the botanical species used as antimalarials that are native to the CPSC is summarised, at the family level, in Fig. 1.

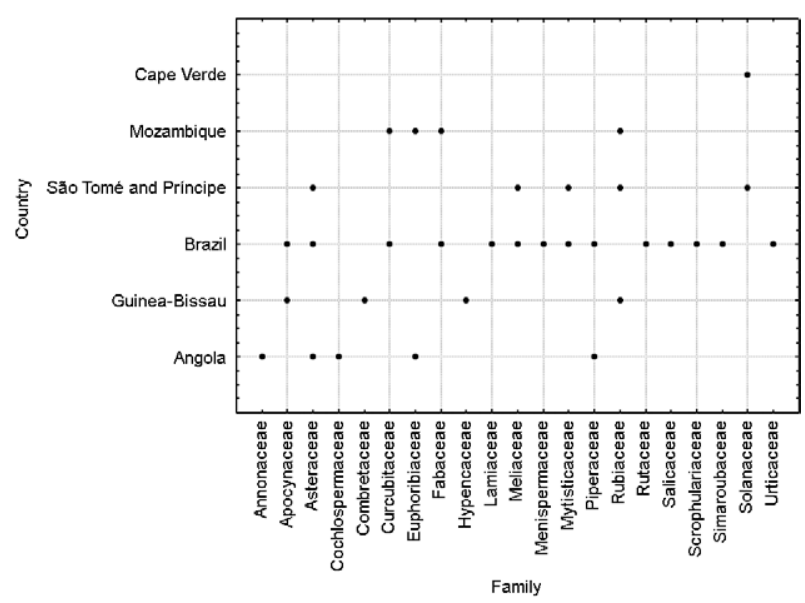

Fig. 1: distribution of plant families studied as antimalarial among Community of Portuguese-Speaking Countries.
Fig. 1 shows the correlation between 21 botanical families and the CPSC. Analysis of this figure indicates that seven families (Apocynaceae, Asteraceae, Cucurbitaceae, Fabaceae, Meliaceae, Myristicaceae and Piperaceae) have species commonly used by the CPSC to treat malaria. The Euphorbiaceae, Rubiaceae and Solanaceae families are represented by botanical species used primarily within African countries. Further, there are reports of other families of plants restricted to some countries: Angola (Annonaceae and Cochlospermaceae), Guinea-Bissau (Combretaceae and Hypencaceae) and Brazil have the most references to species belonging to the seven botanical families. Important correlations between each family, country, studied species, tested parts and scientific data from vitro and in vivo research are also provided in Table.

Brazil - In Brazil, malaria remains endemic in the Amazon, with a mortality of 58 patients out of 306,000 cases per year, largely due to late diagnosis, inadequate treatment or multidrug-resistant parasites. This acute disease presents with typical symptoms (e.g., headache and recurrent fever) and individuals affected by malaria in endemic areas often self-medicate with available antimalarial drugs or medicinal plants.

Three Plasmodium species occur in humans in Brazil: P. falciparum, the most deadly species; Plasmodium vivax, the most prevalent species, causing approximately $80 \%$ of the current cases, according to the Ministry of Health reports, and Plasmodium malariae, the leastprevalent species (Krettli et al. 2001).

There are several studies reporting exotic and native species used popularly in Brazil for the treatment of fever and malaria (Brandão et al. 1992, Milliken 1997, Oliveira et al. 2003, Botsaris 2007, Mariath et al. 2009). Other reviews have focused primarily on the in vitro antimalarial activity of alkaloids, discussing the different chemical classes and structure-activity relationship. Unfortunately, most of these compounds were not evaluated in vivo.

The application of ethnopharmacology in selecting plants with antimalarial uses represents a reasonable approach for identifying new drugs. In fact, in vivo pharmacological evaluation of 22 plants used by popular medicine in Brazil identified four plant species with activity against Plasmodium berghei in mice. The active plants were: Esenbeckia febrifuga (Rutaceae), Lisianthus speciosus (Gentianaceae), Acanthospermum australe (Compositae) and Tachia guyanensis (Gentianaceae) (Brandão et al. 1992). Among the 273 species tested based on random selection, only two, which represents $0.7 \%$, exhibited activity: Vernonia brasiliana (Compositae) and Eupatorium squalidum (Compositae) (Brandão et al. 1992). In another study, 204 extracts were tested from Brazilian Cerrado plants, of which 32 (15.7\%) showed significant parasite growth inhibition at $10 \mu \mathrm{g} / \mathrm{mL}$. The most active families exhibited $\mathrm{IC}_{50}$ values ranging from $0.9 \mu \mathrm{g} / \mathrm{mL}$ (Flacourtiaceae and Sapindaceae) to $4.9 \mu \mathrm{g} / \mathrm{mL}$ (Apocynaceae and Annonaceae) (de Mesquita et al. 2007).

Extracts and active compounds from native species in Brazil that exhibited antimalarial activity are shown in Table. The most active species used in different Brazilian regions are described below. 
Bidens pilosa (Asteraceae), popularly known as picão and picão preto in Brazil, is a species with extensive ethnopharmacological use (de Andrade-Neto et al. 2004). The popular use as an antimalarial was substantiated the crude ethanol extract of the whole plant, leaves and roots at concentrations of $25-50 \mu \mathrm{g} / \mathrm{mL}$. Pharmacological activity was attributed to the presence of polyacetylene and flavonoids (Brandão et al. 1997), which was reinforced by data from Oliveira et al. (2004) correlating these substances with in vivo antimalarial activity.

A recent review on Ampelozizyphus amazonicus (Rhamnaceae), popularly called as cervejeira, cerveja de indio, saracura, curupira-mirá and saracura-mirá, summarised the importance of this native species as an antimalarial in endemic areas (Amaral et al. 2008). Although the prophylactic activity of the crude ethanol extract from the roots of this plant has been proven (Krettli et al. 2001, de Andrade-Neto et al. 2008), the mechanism of action and the active substances of $A$. amazonicus have not yet been identified.

Some botanical species used in folk phytotherapy in Brazil against malaria are known as quinas, for example, Deianira erubescens, Strychnos pseudoquina and Remijia ferruginea (de Andrade-Neto et al. 2003). In this context, ethanol extract from $R$. ferruginea (Rubiaceae) bark, popularly known as quina-da-serra or quina-doBrasil, when evaluated against $P$. berghei, caused inhibition of up to $48 \%$ of parasite growth at a dose of 1,000 $\mathrm{mg} / \mathrm{kg}$ but exhibited only minimal activity at the lower dose of $500 \mathrm{mg} / \mathrm{kg}$ (de Andrade-Neto et al. 2003).

Casearia sylvestris (Flacourtiaceae) is a plant popularly known as guaçatonga and antiplasmodial activity was found with extracts of different parts of this plant, with $\mathrm{IC}_{50}$ values ranging from 0.9 (stem wood) to $2.3 \mu \mathrm{g} /$ $\mathrm{mL}$ (root wood) (de Mesquita et al. 2007).

The Virola surinamensis tree frequently grows on Amazonian riverbanks and is used in folk medicine for a variety of ailments. The Waiãpi Indians treat malaria with this species by inhalation of vapour prepared from leaves of the plant. The essential oil of the leaves $(100 \mu \mathrm{g} /$ $\mathrm{mL}$ ) causes $100 \%$ inhibition in growth from the young trophozoite to schizont development stages and the sesquiterpenoid nerolidol (half of the oil dose) was identified as one of the active compounds (Lopes et al. 1999).

Mozambique - In Mozambique, malaria is the leading cause of morbidity and mortality, accounting for a third of all hospital deaths (USAID 2009). It is estimated that approximately $44,000-67,000$ deaths are attributable to malaria each year (MH 2003). Approximately 9.8 million malaria cases were reported in 2006 (WHO 2009b).

Disease transmission is stable and the presence of the disease is endemic throughout the country due to unaffordable preventive means, favourable temperatures and rain patterns, abundant breeding sites and poverty-related improper housing (Mabunda 2006).

This high prevalence of CQ-resistant (CQR) P. falciparum strains has been reported throughout most of the territory (Mayor et al. 2001). Therapeutic regimens for the treatment of uncomplicated $P$. falciparum infections were changed in 2002 to the combination of S/P + amodiaquine and in 2004 were further altered to $\mathrm{S} / \mathrm{P}+$ artesunate, in line with current WHO recommendations for the use of ACT's (WHO 2006).

In Mozambique, medicinal plants play a key role in basic healthcare (e.g., Verzar \& Petri 1987, Jansen $\&$ Mendes 1991). Approximately 5,500 identified plant species are used in traditional medicine, representing more than 500 plant species (WCMC 1992).

The predominant plant species used in traditional medicine for the treatment of malaria infections as reported by Bandeira et al. (2001) were Acacia karroo Hayne, Acacia nilotica, Senna abbreviata, Adansonia digitata, Alepidea amatymbica, Bridelia cathartica, Crossopteryx febrifuga, Euclea natalensis, Lippia javanica, Momordica balsamina, Rauwolfia caffra, Salacia kraussii, Senna occidentalis, Spirostachys africana, Tabenaemontana elegans, Trichilia emetic and Zanthoxylum capense.

$M$. balsamina is used to cure vomiting with bile and fever, while $S$. africana is used as a therapeutic for headaches. $R$. caffra, which contains alkaloids, is used to treat malaria (van Wyk et al. 1997). B. cathartica is commonly used in southern Mozambique to heal malarial headaches. In Mozambique, a mixture of eucalyptus leaves, avocado and guava is traditionally used to treat bone articulation pain associated with malaria (Kolawole \& Adesoye 2010).

In Central Africa, C. febrifuga root and bark have been used as febrifuge and an antipruritic lotion, respectively. In tropical Africa, the bark is used for fever, malaria, diarrhoea, colic, intestinal worms and application to wounds. This plant is also used for the treatment of syphilitic ulcers and the leaves are used for eye inflammation in neighbouring Tanzania (Maiga et al. 2006).

Although there is a long history of medicinal plant use in Mozambique, research related to the pharmacological evaluation and scientific validation of traditional practices is still very limited, generally covering only ethnobotanical aspects (e.g., Jansen \& Mendes 1990, 1991).

Most studies on the pharmacological activity of plants used by traditional medicine in Mozambique have been conducted with specimens collected in other regions and the obtained results are only indicative because the activity of each plant depends on the region in which it grows or is cultivated (Table).

Results obtained by Ramalhete et al. (2008), with material collected in Mozambique, showed significant antiplasmodial activity for the ethyl acetate extract from aerial parts of M. balsamina $(1.0 \mu \mathrm{g} / \mathrm{mL})$ and for the hexane extract from leaves of $S$. occidentalis $(19.3 \mu \mathrm{g} / \mathrm{mL})$. Another group observed that ethanol extracts from the leaves of $S$. occidentalis had high in vitro antimalarial activity against a $P$. falciparum CQ-sensitive strain $(<3 \mu \mathrm{g} /$ $\mathrm{mL}$ ) (Tona et al. 2004). Interesting in vitro antimalarial activity was also found by Jurg et al. (1991) for crude root ethanol and aqueous extracts and stem ethanol extract of B. cathartica at a concentration of $0.05 \mu \mathrm{g} / \mathrm{mL}$.

Previous studies on the in vitro antimalarial activity of aqueous extracts of leaves and roots from S. abbreviata demonstrated weak activity against $P$. falciparum (Connelly et al. 1996). However, extract from leaves of 


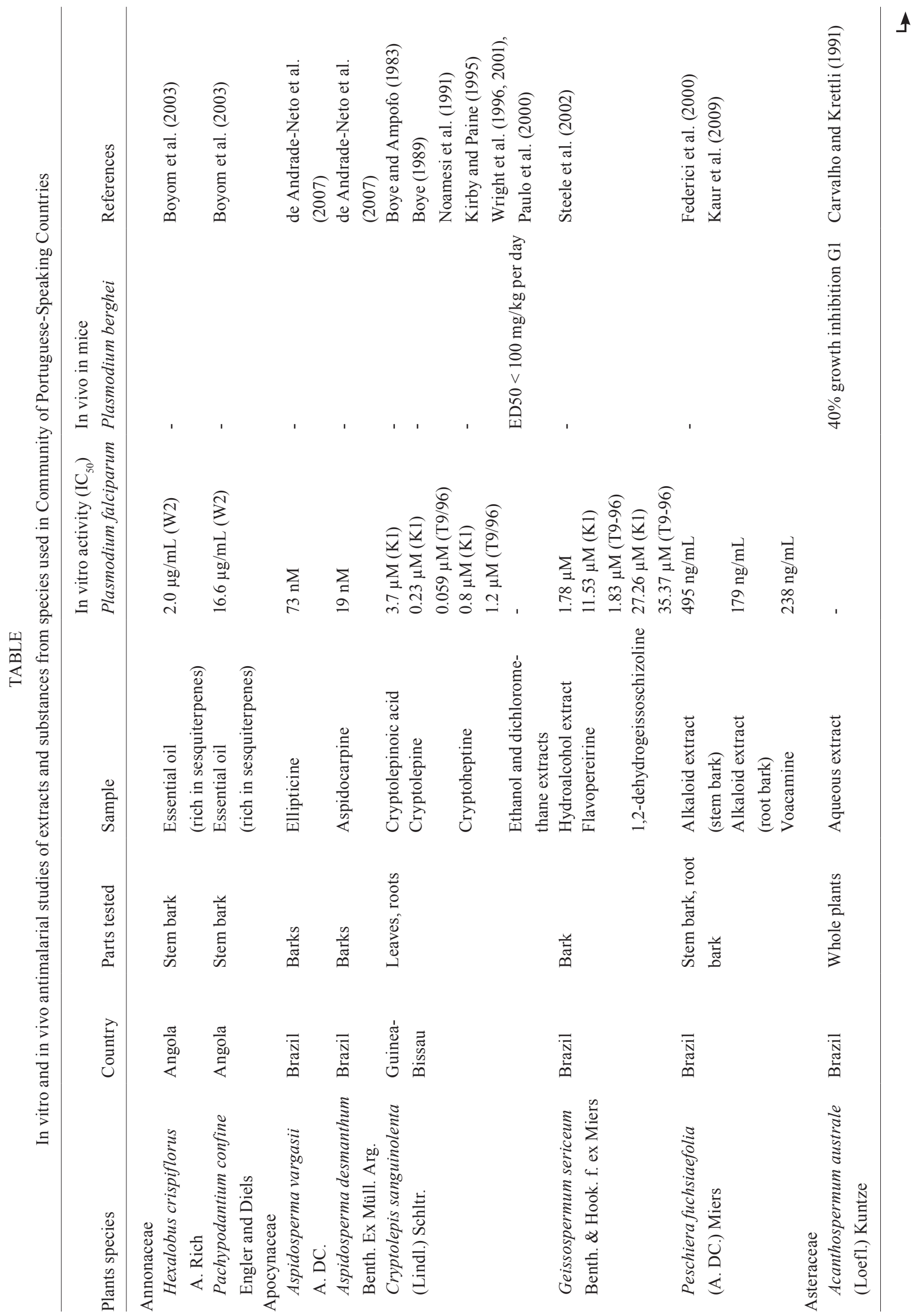




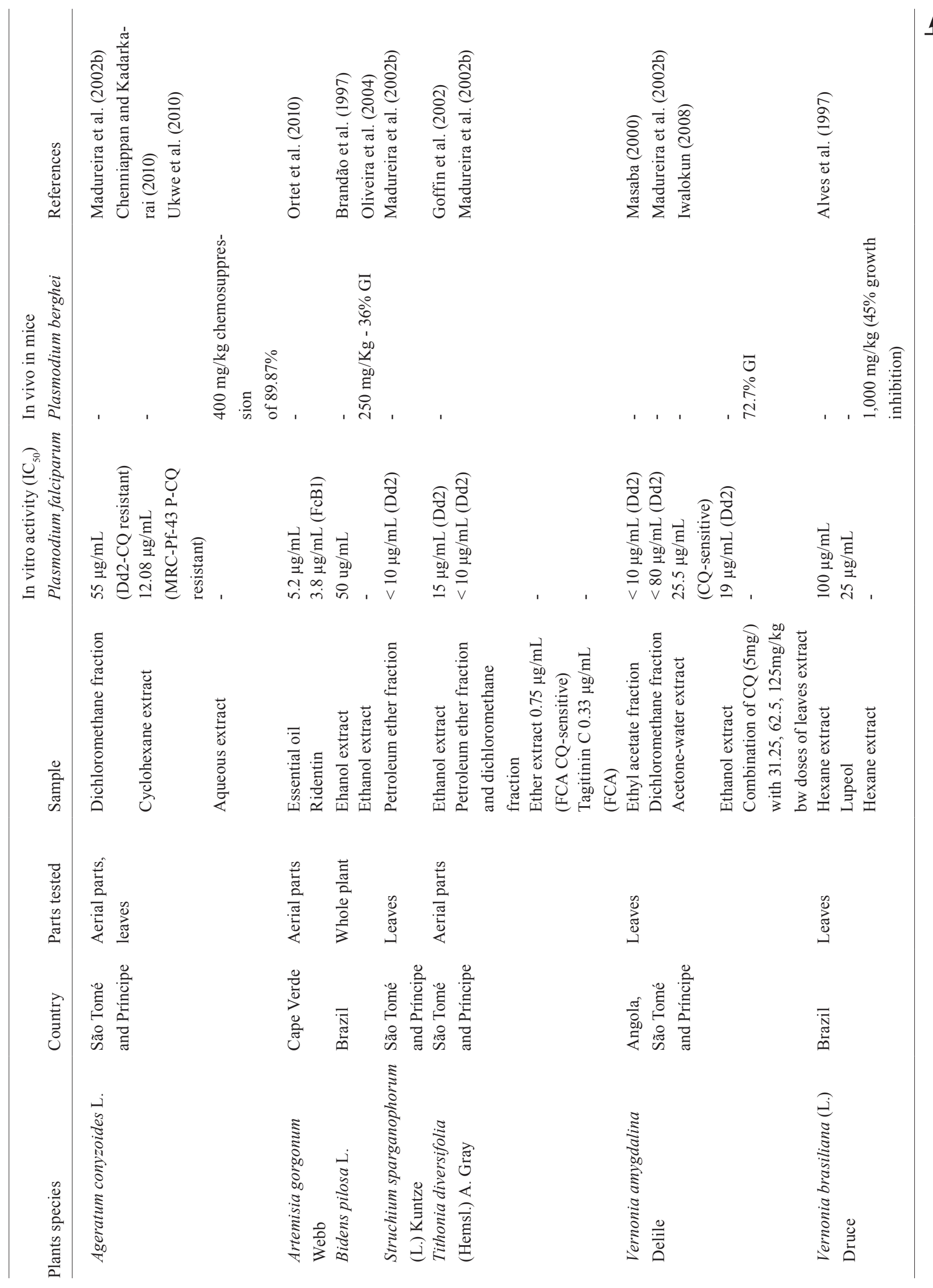




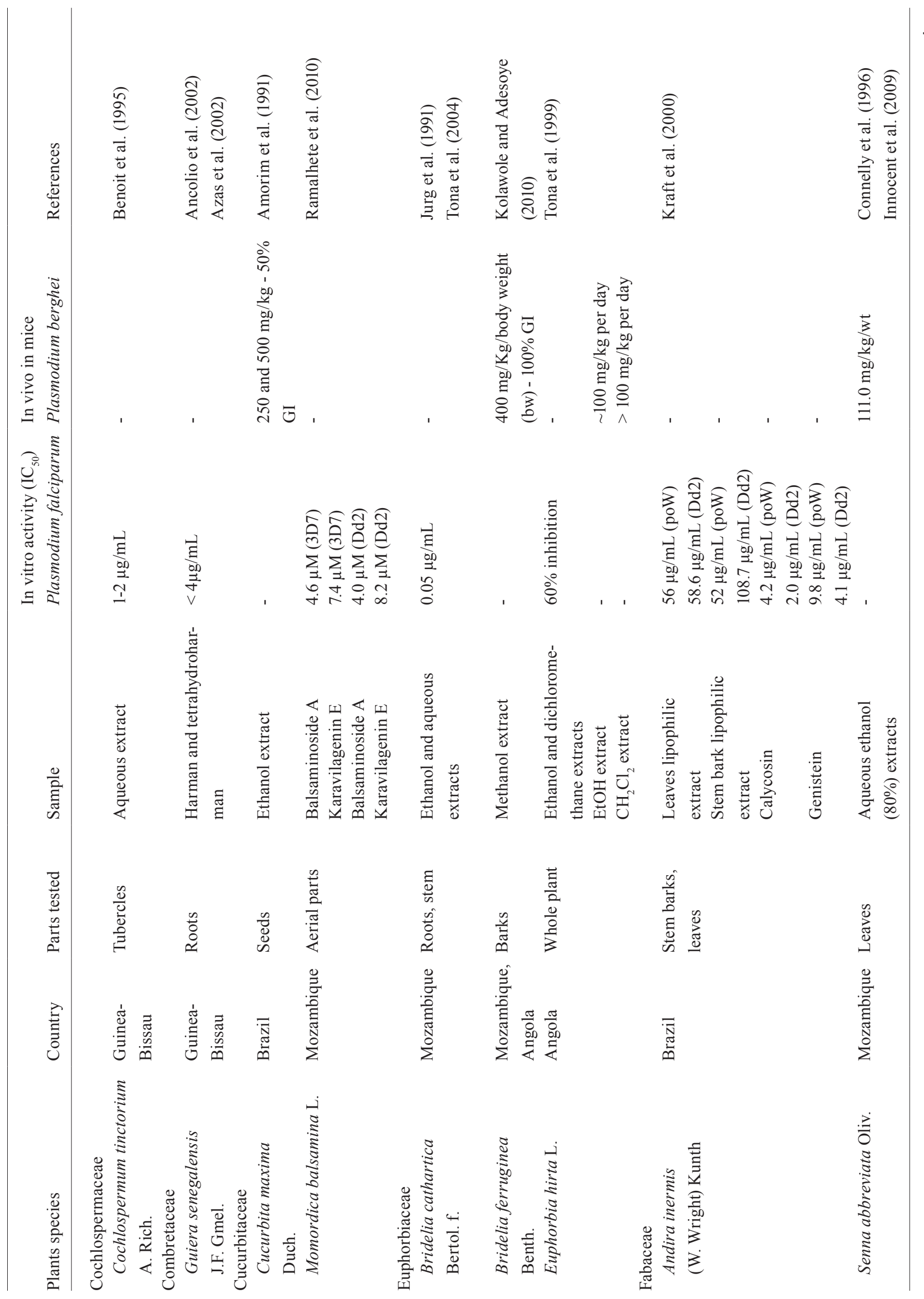




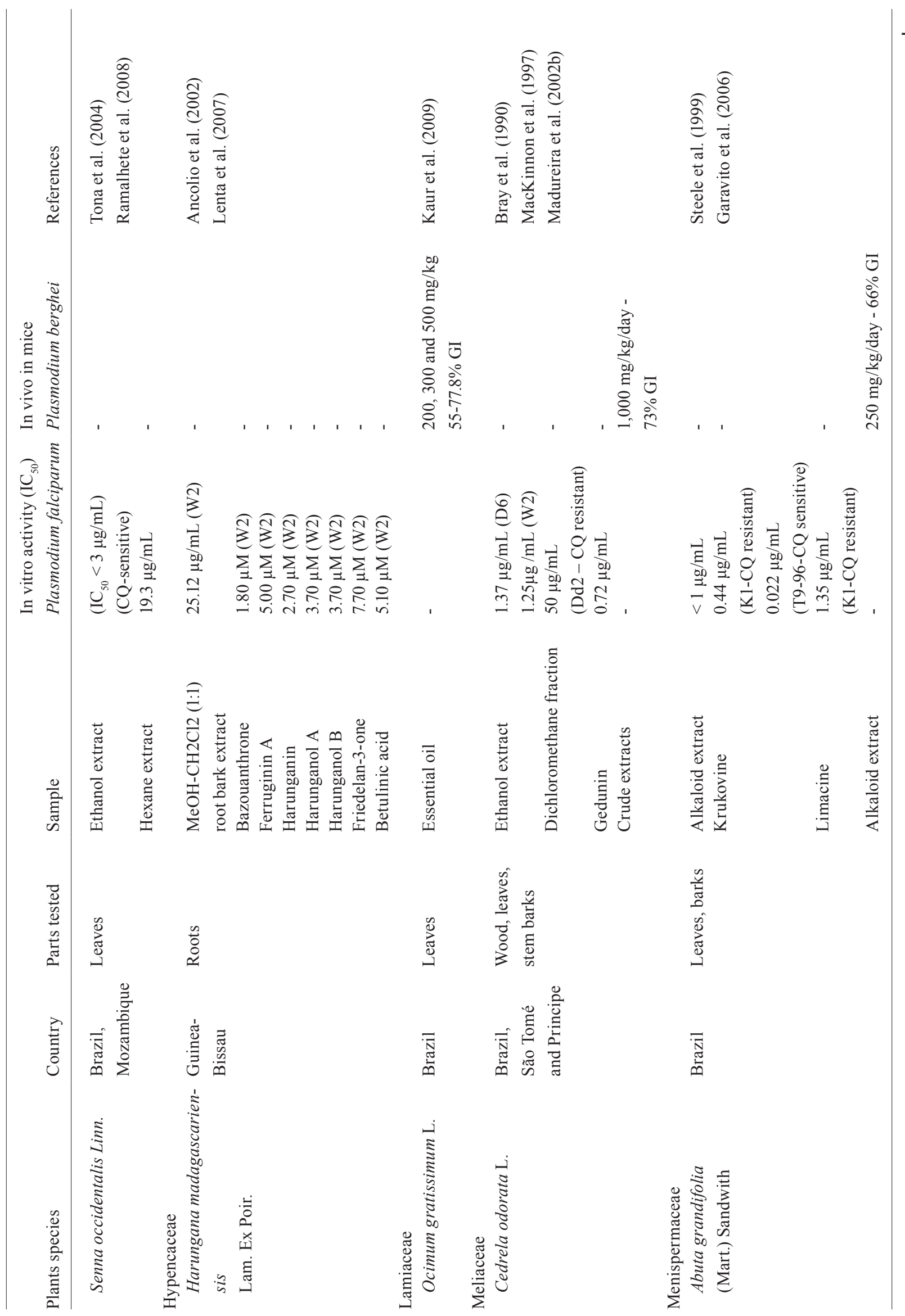




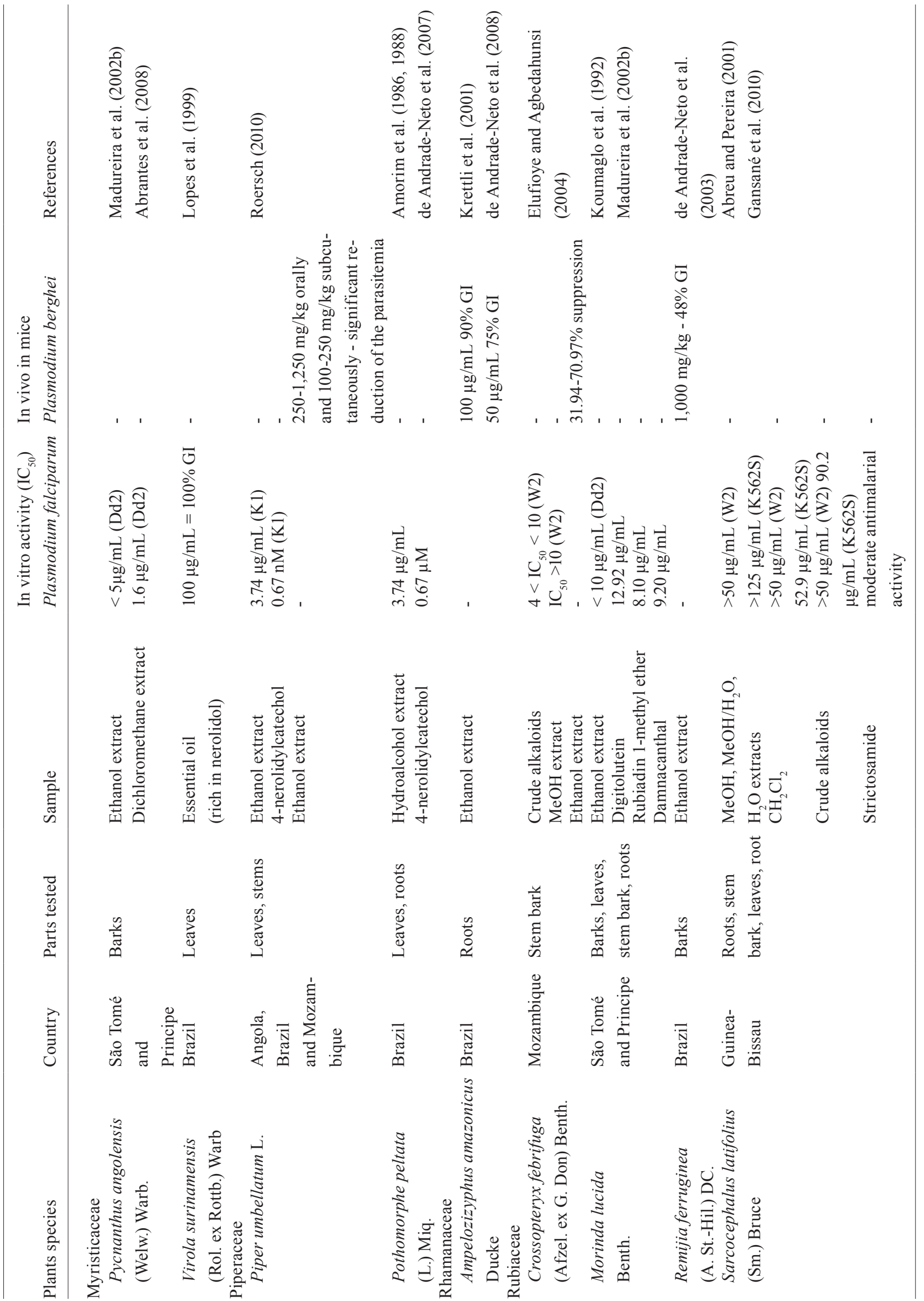




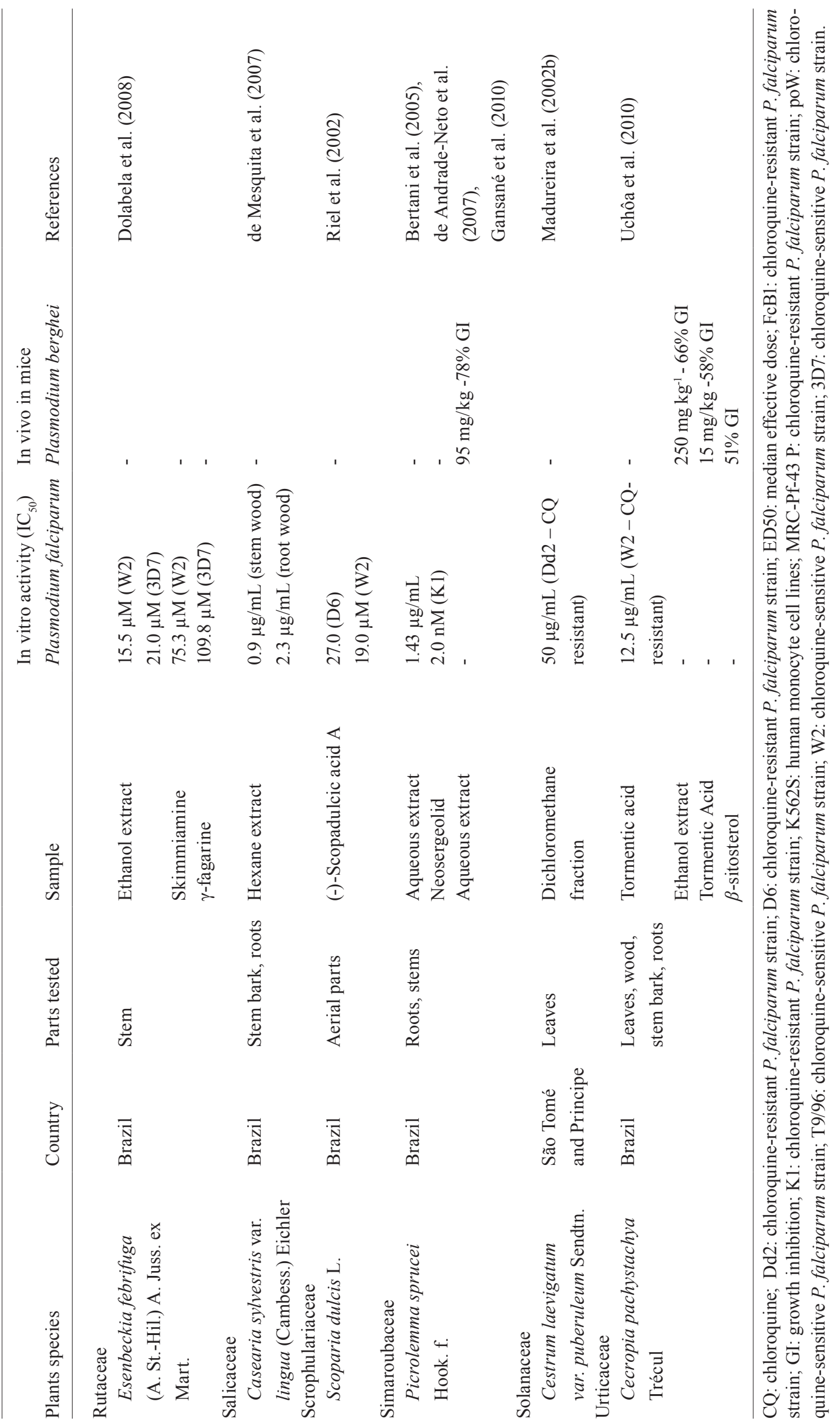


S. abbreviata was associated with in vivo antimalarial activity and these results support the traditional use of this species (Innocent et al. 2009). Of the other species of this genus, $S$. occidentalis is very common and widely distributed around the world. Ethanol extracts from leaves of this species showed a high in vitro antimalarial activity $(<3 \mu \mathrm{g} / \mathrm{mL})$.

The in vitro antimalarial activity of methanol and alkaloid-rich extracts of $C$. febrifuga showed this plant's promise as the source of a malaria treatment (Sanon et al. 2003), which was confirmed in subsequent in vivo assays. The stem bark ethanol extract of $C$. febrifuga was investigated against malaria infections in vivo and the suppression of parasitaemia at the highest dose $(400 \mathrm{mg} /$ $\mathrm{kg}$ ) was similar to CQ at $5 \mathrm{mg} / \mathrm{kg}$ and pyrimethamine at $1.2 \mathrm{mg} / \mathrm{kg}$ (Elufioye \& Agbedahunsi 2004).

Cape Verde - In Cape Verde, malaria is primarily limited to the island of Santiago, with a very low prevalence of approximately 20-40 cases occurring annually. Generally, transmission occurs from September-November (WHO 2011). Malaria has been almost eradicated from the archipelago of Cape Verde (West Africa) following a sustained control programme between 1940-1970. In addition, malaria is considered to be in a pre-elimination phase in the islands and malaria prophylaxis is not recommended for tourists.

Climatic factors and topography are particularly reflected in the diversity of vegetation (Gomes et al. 2008). Medicinal plants are notably helpful in alleviating malaria symptoms such as fever, vomiting and diarrhoea.

Withania chevalieri is a shrub endemic to Cape Verde commonly used by local healers for malaria treatment (Gomes et al. 2008). Artemisia annua is one of the most important species used to treat malaria and several studies in search of other active compounds have been conducted with species of this genus. For example, Artemisia gorgonum volatile oil exhibited mild antiplasmodial activity in vitro $(5.2 \mu \mathrm{g} / \mathrm{mL})$ (Table) and this activity was due, at least in part, to a sesquiterpene lactone, arborescin (2\% in the volatile oil), which was previously reported to inhibit the growth of P. falciparum. The leaves and flowers of $A$. gorgonum were investigated phytochemically and resulted in the isolation of approximately 14 compounds. Most of these compounds exhibited mild antimalarial activities and a sesquiterpene lactone, ridentin, was the most interesting with $\mathrm{IC}_{50}$ value of 3.8 $\mu \mathrm{g} / \mathrm{mL}$ against $P$. falciparum (Ortet et al. 2008).

Guinea-Bissau - In Guinea-Bissau, 1,575 people were infected with malaria in 2008 (WHO 2008). The prevalence of malaria in the community is low. In 1990, a survey of children two-nine years old in rural GuineaBissau showed that $P$. falciparum was the most prevalent parasite (Jaenson et al. 1994).

CQR P. falciparum was first reported in GuineaBissau in 1990 (Hellgren et al. 1991). Since then, Plasmodium resistance has been monitored annually and results have indicated stability in the level of CQR parasites, despite the continued widespread use of CQ (Ursing et al. 2007).
In 2006, the malaria treatment policy in Guinea-Bissau was changed to artemether-lumefantrine as the first-line treatment of uncomplicated malaria. In practice, $\mathrm{CQ}$ is still used widely, with $\mathrm{S} / \mathrm{P}$ as the second choice. In vivo studies have shown moderate but stable efficacy of CQ over the years (Kofoed et al. 2002, Rodrigues et al. 2008).

In 2006, a survey was conducted in Guinea-Bissau to contribute to the knowledge of medicinal plants of the country, and ethnopharmacological information on 150 plants used as medicine was assembled. Out of these 150 plants, Diniz et al. (2000) described 25 species with their vernacular names and uses in traditional medicine for the treatment of several diseases. In this list, only three medicinal plants are traditionally used in malaria treatment. Gomes et al. (2003) reported only six plants species used in ethnomedicine in Guinea-Bissau to treat malaria: Sarcocephalus latifolius, Lippia chevalieri, Guiera senegalensis, Gardenia ternifolia, Piliostigma thonningi and Harungana madagascariensis. Diniz et al. (2008) reported the use of Zanthoxylum leprieuri, S. latifolius and Cryptolepis sanguinolenta in malaria treatment. Out of the known plants used in traditional medicine in Guinea-Bissau, only C. sanguinolenta and Cochlospermum tinctorium were collected in the country and tested. There have been no studies with the other known medicinal plants used in Guinea-Bissau, as has been reported for other countries in Africa. Several studies were conducted with botanical species collected in different regions, thus preventing scientific validation of their use in traditional medicine in Guinea-Bissau.

Data presented below and in Table demonstrated the usefulness of some species as antimalarials in other endemic areas and the importance of testing to validate their traditional uses.

C. sanguinolenta is rich in indoloquinoline alkaloids. Crytoplepine, the predominant and the most studied alkaloid, has potent in vitro antimalarial activity (Noamesi et al. 1991, Kirby \& Paine 1995, Wright et al. 1996, 2001, Cimanga et al. 1997) and action similar to CQ (Onyeibor et al. 2005).

The roots of $C$. tinctorium, traditionally called Djánderé in Guinea-Bissau (Bouquet 1968), are used in the treatment of liver diseases and malaria infection (Gomes et al. 2003). Benoit et al. (1995) performed in vitro assays with sensitive and resistant $P$. falciparum strains and established C. tinctorium antimalarial activity. Other studies of the extracts and essential oils prepared from leaves of this species of $C$. tinctorium also exhibited antiplasmodial activity (Benoit-Vical et al. 1999).

The indole alkaloid, strictosamide, was isolated from the root extract of S. latifolius and displayed moderate in vitro antimalarial activity against $P$. falciparum (Abreu $\&$ Pereira 2001). The evaluation of in vitro antimalarial activity of extracts from leaves showed that it was inactive against W2 strains with an $\mathrm{IC}_{50}$ value greater than 50 $\mu \mathrm{g} / \mathrm{mL}$ (Gansané et al. 2010).

G. senegalensis has been used in the treatment of acute gastroenteritis and dysentery and as an antimalarial agent (Etkins \& Ross 1982, Etkins 1988). Chloroform extract of G. senegalensis roots exhibited pronounced antimalarial activity, although fractions obtained from 
this extract did not exhibit a significant increase in antimalarial activity compared with the crude extract. Two alkaloids isolated from the active extract of $G$. senegalensis, harman and tetrahydroharman, showed antimalarial activity $(<4 \mu \mathrm{g} / \mathrm{mL}$ ) (Ancolio et al. 2002) and the latter did not present cytotoxicity and genotoxicity in the Salmonella Ames test (Azas et al. 2002).

An interesting in vitro synergistic antimalarial effect observed among compounds and extracts obtained from three plants commonly used as traditional remedies has been well demonstrated. Mitragyna inermis (total alkaloids + ursolic acid), Nauclea latifolia (total alkaloids) and Feretia apodanthera (methanol fraction) together with G. senegalensis (harman + tetrahydroharman) in different associations showed synergism. These combinations showed a strong and synergistic inhibitory effect in vitro (Azas et al. 2002). This work suggests that these associations can be considered good candidates for antimalarial combination therapy.

The leaves and stem bark of $H$. madagascariensis are used in ethnomedicine for the treatment of anaemia. The stem bark is also employed for nephrosis, malaria, gastrointestinal disorders and fever (Iwalewa et al. 2008). The stem bark ethanol extract showed significant antimalarial activity $(0.517 \mu \mathrm{g} / \mathrm{mL}, \mathrm{CQ}$ reference drug), thus indicating their positive role and justifying the use of this species in traditional medicine (Iwalewa et al. 2008).

The quinones bazouanthrone, harunganin, harunganol A, harunganol B and the terpenes feruginin A, friedelan-3-one and betulinic acid have been isolated from the root bark of this species of $H$. madagascariensis and they have shown in vitro antimalarial activity against the W2 strain of $P$. falciparum, of which bazouanthrone $\left(\mathrm{IC}_{50}\right.$ of $1.80 \mathrm{mM}$ ) was the most active (Lenta et al. 2007).

STP - Malaria has long been a problem in STP, which stresses the health systems and hampers the economic development of the country (Teklehaimanot et al. 2009).

According to Martet et al. (1991), "Malaria has existed for a very long time on the archipelago. It is characterised by a permanent transmission with seasonal outbreaks that correspond with the end of the rainy season and the start of the dry one (April-May). Another slightly smaller peak occurs from November-December. Transmission decreases with altitude: above $300 \mathrm{~m}$ of altitude the bio-ecology of the main vector (Anopheles gambiae) and the drop in the density of the human population cause the transmission to decline.". Although all four species of Plasmodium have been detected, (Ceita 1986, Martet et al. 1991, Loureiro et al. 1996, Baptista et al. 1997, Lopes et al. 2002), $P$. falciparum predominates with prevalence rates exceeding $70 \%$ in some districts before the recent intensification (Pinto et al. 2000a). An. gambiae s.s. is the only malaria vector in the country (Pinto et al. 2000b).

In 2005, the National Centre of Endemic Diseases drafted a national malaria control strategy, which produced a rapid decline in malaria morbidity and mortality on the island of Príncipe. Confirmed malaria cases decreased from the annual average of 38,655 during 2000-2005 to 3,893 cases in 2009 ( $90 \%$ decline). In the same period, malaria admissions fell from an annual average of 12,367 to 1,514 in 2009 ( $88 \%$ decline) and malaria deaths also fell from 23 to 16 . However, in 2009, the number of confirmed malaria cases increased from 1,647 to 3,893 , a $140 \%$ increase since 2008 (WHO 2010). Malaria-related admissions rose from 850-950 (up 44\%) and malaria-related deaths increased from 16 to 23 (up $44 \%$ ). The reasons for this resurgence may be linked to the absence of indoor residual spraying (IRS), which was not implemented during 2008. Once the increase in cases was detected by the surveillance system, emergency IRS was implemented and malaria cases decreased during the second half of 2009 (WHO 2010).

On these islands, a large number of medicinal plants have been used for centuries by traditional medicine and there are many places where western medicine is practically nonexistent, if not nonexistent. There are few ethnobotanical records of the flora of STP, and those that exist are quite restricted (Madureira 2008).

Roseira (2004) compiled one of the few existing ethnobotanical records of the Santomean flora. Sequeira (1994) published an article about the uses of 53 medicinal plants.

Between 1993-2001, an extensive ethnopharmacology study was conducted, collecting information on 325 botanical species and recording more than 1,000 ways to prepare traditional remedies and their uses (Madureira et al. 2002b).

Among the catalogued species, six plants representing four families were found to be commonly used in the treatment of malaria/fever: Morinda lucida (Rubiaceae), Cedrela odorata (Meliaceae), Tithonia diversifolia (Asteraceae), Vernonia amygdalina (Asteraceae), Ageratum conyzoides (Asteraceae) and Pycnanthus angolensis (Myristicaceae).

Other plants, such as Leonotis nepitifolia, Struchium sparganophorum and Cestrum laevigatum, have also been reported as being commonly employed in the traditional medicine of STP. However, scientific data related to these species are largely nonexistent.

Madureira et al. (2002a) reported that extracts and fractions from $S$. sparganophorum have showed significant antimalarial activity in in vitro tests and in vivo assays (Table).

Traditionally, the roots, stem bark and leaves of $M$. lucida are widely used in tropical Africa due to their reputed therapeutic value in the treatment of antiparasitic diseases (Kambu 1990), such as malaria (Obih et al. 1985, Asuzu \& Chineme 1990, Agomo et al. 1992, Koumaglo et al. 1992, Tona et al. 1999, Bello et al. 2009). Investigating the antimalarial activity of this medicinal plant, Obih et al. (1985) reported the effect of methanol extracts of the stem bark, leaves and root bark against $P$. berghei in mice, where the juice from fresh leaves at a 1:6 dilution showed a decrease in parasitaemia from the second day of treatment. A fraction obtained from the stem bark extract of this plant demonstrated antimalarial activity in vivo and the highest dose produced $96.4 \%$ suppression of parasitaemia (Obih et al. 1985).

Phytochemical analyses revealed that M. lucida contains various types of alkaloids-anthraquinones and anthraquinols (Adewunmi \& Adesogan 1984). In fact, Koumaglo et al. (1992) associated the antiplasmodial 
activity of M. lucida stem bark and root to the presence of the anthraquinones digitolutein, rubiadin-1-methylether and damnacanthal.

C. odorata is considered one of the most valuable forest tree species in the tropics and is also one of the most widely distributed (Millán-Orozco et al. 2011). In the tropics, species of the Meliaceae family are extensively used as traditional medicine against malaria (Khalid et al. 1986, Phillipson \& Wright 1991, Leaman et al. 1995) and fevers (Ayensu et al. 1981), a characteristic symptom of malaria. In Africa, the decoction of $C$. odorata barks is used against this disease (Madureira 2008) and antimalarial activity of some compounds in bark and leaves was reported (MacKinnon et al. 1997, Omer et al. 2003).

In work by MacKinnon et al. (1997), extracts of 22 species of Meliaceae, including $C$. odorata, were examined for their antimalarial activity using in vitro tests with two clones of $P$. falciparum, one sensitive to CQ (W2) and one CQR (D6). The ethanol extract of C. odorata wood exhibited the highest activity against both clones, with $\mathrm{IC}_{50}$ values of $1.25 \mu \mathrm{g} / \mathrm{mL}$ (D6) and $1.37 \mu \mathrm{g} / \mathrm{mL}$ (W2). This activity was associated with the presence of tetranortriterpenoids (limonoids), a class of compounds characteristic of the Meliaceae family (MacKinnon et al. 1997).

A member of the family Asteraceae, T. diversifolia, is widely used for the treatment of malaria in STP (Elufioye \& Agbedahunsi 2004, Owoyele et al. 2004, Moronkola et al. 2007).

The importance of this species as an antimalarial has been documented by many authors who found activity for the nonpolar and medium polarity extracts (Goffin et al. 2002, Madureira et al. 2002a, Elufioye \& Agbedahunsi 2004).

As expected for a member of Asteraceae family, this species contains sesquiterpene lactones tagitinin A-C and $\mathrm{F}$. Tagitinin $\mathrm{C}$ was reported as an active antiplasmodial component $(0.33 \mu \mathrm{g} / \mathrm{mL})$, which also possessed cytotoxic properties $\left(\mathrm{IC}_{50}\right.$ on HTC-116 cells: $0.706 \mu \mathrm{g} /$ $\mathrm{mL}$ ) (Goffin et al. 2002).

V. amygdalina, from the Asteraceae family, is commonly known as "bitter leaf" and often appears in traditional medicines in Africa. Acetone-water and ethanol extracts of the leaves showed crescent antiplasmodial activity (Masaba 2000, Madureira et al. 2002a, Iwalokun 2008). In addition, this species achieved special relevance, having been shown to possess potent antimalarial activity in human medicine (Abosi \& Roseroka 2003).

Other pharmacological studies of $V$. amygdalina have demonstrated the inherent ability of aqueous leaf extract to assist the restoration of CQ efficacy as a prophylactic and chemotherapeutic agent against CQ-sensitive and resistant $P$. berghei infection in mice (Iwalokun 2008).

Also belonging to the Asteraceae family, preliminary evaluation of the antimalarial activity of $A$. conyzoides demonstrated that the aqueous extract of leaves exhibited dose-dependent activity in infected mice. At the dose of $400 \mathrm{mg} / \mathrm{kg}$, this extract produced chemosuppression of $89.87 \%$, which is higher than that of CQ $(83.12 \%)$ at $5 \mathrm{mg} / \mathrm{kg}$, indicating high antimalarial potential (Ukwe et al. 2010). It was also reported that non-polar extract of the leaves has moderate in vitro antiplasmodial activity (12.08 $\mu \mathrm{g} / \mathrm{mL})($ Chenniappan \& Kadarkarai 2010).
Dichloromethane, methanol and aqueous ethanol extracts of $P$. angolensis barks were evaluated for their in vitro antimalarial activity and dichloromethane extract was the most effective $\left(\mathrm{IC}_{50}\right.$ of $\left.1.6 \mu \mathrm{g} / \mathrm{mL}\right)$ (Abrantes et al. 2008).

Angola - Malaria is the leading cause of morbidity and mortality in Angola. According to the National Malaria Control Programme, four million clinical cases and 20,000 deaths were reported in 2005, accounting for 35\% of the overall mortality in children under five and $25 \%$ of maternal deaths (WHO 2005). Malaria is endemic in most areas of the Angolan territory, with P. falciparum as the predominant infecting species (WHO 2005). The epidemiological characteristics of malaria in Angola vary from hyper-endemic (northern and north-eastern of the country) to mesoendemic stable and mesoendemic unstable (Menegon et al. 2009).

Angola is rich in many medicinal plants whose potential has yet to be explored. However, there is some information about medicinal plants in this country and their uses for the treatment of malaria. The primary species associated with disease treatment are Artemisia afra, Gardenia jovis-tonantis, V. amygdalina, Conysa welwitschii, Lantana camara, Harungana madagascarensis, Psorosperum febrifugum, Paveta schumanniana, Crassocephalum rubens, Crassocephalum multicorymbosum and Cajanus cajan (Van-Dúnem 1994, Bossard 1996).

Bridelia ferruginea is a shrub found in northern Angola that is popularly used to treat malaria. Kolawole \& Adesoye (2010) conducted a study to evaluate the antimalarial activity of this species with a sensitive strain of P. berghei (Table). An extract of Cochlospermum angolense root, popularly used in Angola for the prophylaxis of malaria, exhibited in vitro activity against $P$. falciparum $(50 \mu \mathrm{g} / \mathrm{mL})$ (Presber et al. 1992).

Piper umbellatum is common species in Angola, Mozambique and Brazil, especially in the Amazon Region. This plant has been used to treat malaria and there has been a study describing the active compound of this species (de Andrade-Neto et al. 2008).

Another widespread species, $V$. amygdalina, is also used to treat malaria in Angola and recent in vivo studies carried out in Nigeria have shown the effectiveness of this species (Iwalokun 2008).

The stem bark essential oil of Hexalobus crispiflorus, characterised by high sesquiterpene content (99.5\%), showed high activity against $P$. falciparum $(2.0 \mu \mathrm{g} / \mathrm{mL})$. Another species, Pachypodanthium confine, whose stem bark essential oil has lower amounts of sesquiterpenes $(88 \%)$, was also assayed against the same strains. Results showed that the activity $(16.5 \mu \mathrm{g} / \mathrm{mL})$ was lower than that observed for $H$. crispiflorus essential oil. The authors suggested that the sequiterpene content could be responsible for the antimalarial properties (Boyom et al. 2003).

Correlation among genera from the CPSC, extracts and antimalarial active chemical classes - Fig. 2 shows thatterpenes and alkaloids are the dominant classes of substances with antimalarial activity found in the studied extracts. Active terpenes were found in hydrophilic and lipophilic extracts from twelve genera (Cecropia, 
Cedrela, Hexalobus, Pothomorphe, Artemisia, Scoparia, Pachypodantium, Tithonia, Piper, Virola, Picrolem$m a$ and Ocimum). Active alkaloids were found in eight genera (Abuta, Esenbeckia, Guiera, Aspidosperma, Harungana, Sarcocephalus, Geissospermum and Cryptolepsis), the majority of which were obtained from alcohol or crude alkaloid extracts. Phenolics, from lipophilic extracts of Andira and Harungana, and steroids, from extracts of Cecropia, Vernonia, Harungana and Momordica, are additional active antimalarial classes that have been previously studied (Fig. 2).

Final considerations - Of the countries covered in this review, Brazil had the largest number of native species studied and active substances identified for the treatment of malaria parasites. The ethnopharmacological work in STP resulted in important surveys about medicinal plants popularly used in the region. It is important to emphasise that many of the studies using the African species were not performed at the place of their harvest, which can lead to changes in chemical composition with probable alterations to therapeutic action.

Regarding common use among the CPSC, Brazil and Mozambique share the common use of species from the botanical Fabaceae and Cucurbitaceae families. Among Fabaceae species, $S$. occidentalis is employed to treat malaria in both countries. Within the Cucurbitaceae family, there are reports on the common use of two taxa, Cucurbita maxima and M. balsamina.

In Brazil and STP, three botanical species distributed among the Myristicaceae and Meliaceae families have ethnopharmacological uses for malaria treatment and studies have corroborated their pharmacological activity against $P$. falciparum. In this context, two species of Myristicaceae, $V$. surinamensis and $P$. angolensis, occur in ecosystems in Brazil and Africa, respectively. The decoction of $C$. odorata bark of the Meliaceae family is popularly used in the same manner in both countries.

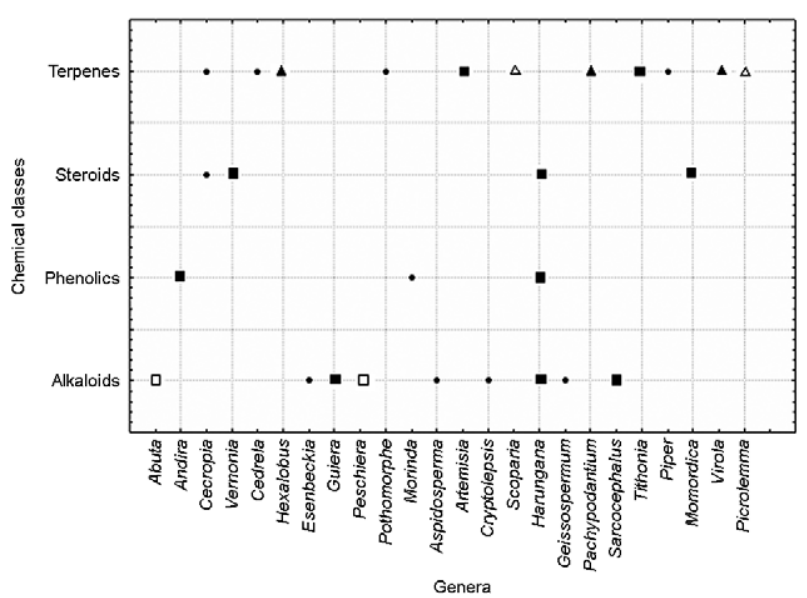

Fig. 2: comparison among genera from Community of PortugueseSpeaking Countries and antimalarial active chemical classes: $\bullet$ : alcohol extract; $\mathbf{\Lambda}$ : essential oil; $\mathbf{\square}$ : lipophilic extract; $\triangle$ : aqueous extract; $\square:$ alkaloid extract.
Eight botanical species of the Asteraceae family are distributed within four countries of the CPSC: three in Brazil (A. australe, B. pilosa and V. brasiliana), three in STP (A. conyzoides, $S$. sparganophorum and T. diversifolia) and one in Cape Verde (A. gorgonum). V. amygdalina is a commonly used botanical species in Angola and STP. The Piperaceae family is represented by two plant species, Pothomorphe peltata (Brazil) and P. umbellatum (Angola, Brazil and Mozambique), which are both employed to treat malaria.

There is a wide biodiversity in these countries that has not yet been thoroughly explored that represents a treasure of useful information in the search for antimalarials or treatments for other diseases.

\section{REFERENCES}

Abosi AO, Roseroka BH 2003. In vivo antimalarial activity of Vernonia amygdalina. Br J Biomed Sc 60: 89-91.

Abrantes M, Mil-Holmens T, Duarte N, Lopes D, Cravo P, Madureira MC, Ferreira M 2008. Antiplasmodial activity of lignans and extracts from Pycnanthus angolensis. Planta Med 74: 1405-1408.

Abreu P, Pereira A 2001. New indole alkaloids from Sarcocephalus latifolius. Nat Prod Lett 15: 43-48.

Adewunmi CO, Adesogan EK 1984. Anthraquinones and oruwacin from Morinda lucida as possible agents in fasciolasis and schistosomiasis control. Fitoterapia 55: 259-263.

Agomo PU, Idigo JC, Afolabi BM 1992. Antimalarial medicinal plants and their impact on cell populations in various organs of mice. Afr J Med Med Sci 21: 39-46.

Alves TMA, Nagem TJ, Carvalho LH, Krettli, Zani CL 1997. Antiplasmodial triterpene from Vernonia brasiliana. Planta Med 63: 554-555.

Amaral ACF, Ferreira JLP, Moura DF, Carvalho JR, Ohana DT, Echevarria A, Rosário VE, Lopes D, Silva JRA 2008. Updated studies on Ampelozizyphus amazonicus, a medicinal plant used in the Amazonian Region. Pharmacognosy Reviews 2: 308-316.

Amorim CZ, Flores CA, Gomes BE, Marques AD, Cordeiro RSB 1988. Screening for antimalarial activity in the genus Pothomorphe. J Ethnopharmacol 24: 101-106.

Amorim CZ, Gomes BE, Flores CA, Cordeiro RSB 1986. Antimalarial activity screening from plants of the genus Pothomorphe. Braz J Med Biol Res 19: 569A.

Amorim CZ, Marques AD, Cordeiro RSB 1991. Screening of the antimalarial activity of plants of the Cucurbitaceae family. Mem Inst Oswaldo Cruz 86 (Suppl. II): 177-180.

Ancolio C, Azas N, Mahiou V, Ollivier E, Di Giorgio C, Keita A, Timon-David P, Balansard G 2002. Antimalarial activity of extracts and alkaloids isolated from six plants used in traditional medicine in Mali and São Tome. Phytother Res 16: 646-649.

Asuzu IU, Chineme CN 1990. Effects of Morinda lucida leaf extract on Trypanosoma brucei brucei infection in mice. J Ethnopharmacol 30: 307-313.

Ayensu ES 1981. Medicinal plants of West Africa, Reference publications Inc, Algonac, 330 pp.

Azas N, Laurencin N, Delmas F, Di GC, Gasquet M, Laget M, TimonDavid P 2002. Synergistic in vitro antimalarial activity of plant extracts used as traditional herbal remedies in Mali. Parasitol Res 88: 165-171.

Bandeira SO, Gaspar F, Pagula FP 2001. African ethnobotany and healthcare: emphasis on Mozambique. Pharm Biol 39: 70-73. 
Baptista JL, Das Neves I, D’Alessandro U, Hendrix L, Wéry M 1997. Plasmodium falciparum chloroquine and quinine sensitivity in asymptomatic and symptomatic children in São Tomé Island. Trop Med Int Health 2: 582-588.

Bello S, Oduola T, Adeosun OG,Omisore NOA, Raheem GO, Ademosun AA 2009. Evaluation of antimalarial activity of various fractions of Morinda lucida leaf extract and Alstonia boonei stem bark. Global J Pharm 3: 163-165.

Benoit F, Valentin A, Pélissier Y, Marion C, Dakuyo Z, Mallié M, Bastide JM 1995. Antimalarial activity in vitro of Cochlospermum tinctorium tubercle extracts. Trans $R$ Soc Trop Med Hyg 89: 217-218.

Benoit-Vical F, Valentin A, Mallié M, Bastide JM, Bessière JM 1999. In vitro antimalarial activity and cytotoxicity of Cochlospermum tinctorium and C. planchonii leaf extracts and essential oils. Planta Med 65: 378-381.

Bertani S, Bourdy G, Landau I, Robinson JC, Esterre Ph, Deharo E 2005. Evaluation of French Guiana traditional antimalarial remedies. J Ethnopharmacol 98: 45-54.

Bossard E 1996. La médecine traditionnelle au centre et à l'ouest de l'Angola, 1996, Instituto de Investigação Cientifica Tropical, Lisbonne, $531 \mathrm{pp}$.

Botsaris AS 2007. Plants used traditionally to treat malaria in Brazil: the archives of Flora Medicinal. J Ethnobiol Ethnomed 3: 18-26.

Bouquet A 1968. Preliminary chemical studies on certain medicinal plants of Congo-Brazzaville. Med Trop 28: 49-58.

Bourdy G, Willcox ML, Ginsburg H, Rasoanaivo P, Graz B, Deharo E 2008. Ethnopharmacology and malaria: new hypothetical leads or old efficient antimalarials? Int J Parasitol 38: 33-41.

Boye GL 1989. Studies on antimalarial action of Cryptolepis sanguinolenta extract. In The International Symposium on East-West Medicine, Seoul, p. 243-251.

Boye GL, Ampofo O 1983. Proceedings of the First International Symposium on Cryptolepine, Ghana, p. 37-40.

Boyom FF, Ngouana V, Zollo PH, Menut C, Bessiere JM, Gut J, Rosenthal PJ 2003. Composition and anti-plasmodial activities of essential oils from some Cameroonian medicinal plants. Phytochemistry 64: 1269-1275.

Brandão MGL, Dubois AL, Teixeira MA, Wagner HA 1992. Triterpene saponins from roots of Ampelozizyphus amazonicus. Phytochemistry 31: 352-354.

Brandão MGL, Kretlli AU, Soares LSR, Nery CGC, Marinuzzi HC 1997. Antimalarial activity of extracts and fractions from Bidens pilos $a$ and other Bidens species (Asteraceae) correlated with the presence of acetylene and flavonoid compounds. J Ethnopharmacol 57: 131-138.

Bray DH, Warhust DC, Connolly JD, O’Neill MJ, Phillipson JD 1990. Plants as sources of antimalarial drugs. Part 7. Activity of some species of Meliaceae plants and their constituent limonoids. Phytother Res 4: 29-35.

Carvalho LH, Krettli AU 1991. Antimalarial chemotherapy with natural products and chemically defined molecules. Mem Inst Oswaldo Cruz 86 (Suppl. II): 181-184.

Ceita JGV 1986. Malaria in São Tomé and Príncipe. In Proceedings of the Conference on Malaria in Africa, American Institute of Biological Sciences, Washington DC, p. 142-155.

Chenniappan K, Kadarkarai M 2010. In vitro antimalarial activity of traditionally used Western Ghats plants from India and their interactions with chloroquine against chloroquine-resistant Plasmodium falciparum. Parasitol Res 107: 1351-1364.
Cimanga K, De Bruyne T, Pieters L, Vlietinck AJ, Turger CA 1997. In vitro and in vivo antiplasmodial activity of cryptolepine and related alkaloids from Cryptolepis sanguinolenta. J Nat Prod 60: 688-691.

Connelly MPE, Fabiano E, Patel IH, Kinyanjui SM, Mberu EK, Watkins WM 1996. Antimalarial activity in crude extacts of Malawian medicinal plants. Ann Trop Med Parasitol 90: 597-602.

de Andrade-Neto VF, Brandão MG, Nogueira F, Rosário VE, Krettli AU 2008. Ampelozyziphus amazonicus Ducke (Ramnaceae), a medicinal plant used to prevent malaria in the Amazon Region, hampers the development of Plasmodium berghei sporozoites. Int J Parasitol 38: 1505-1511.

de Andrade-Neto VF, Brandão MGL, Oliveira FQ, Casali VW, Njaine B, Zalis MG, Oliveira LA, Kretlli AU 2004. Antimalarial activity of Bidens pilosa L. (Asteraceae) ethanol extracts from wild plants collected in various localities or plants cultivated in humus soil. Phytotherapy Res 18: 634-639.

de Andrade-Neto VF, Brandão MGL, Stehmann JR, Oliveira LA, Krettli AU 2003. Antimalarial activity of Cinchona-like plants used to treat fever and malaria in Brazil. J Ethnopharmacol 87: 253-256.

de Andrade-Neto VF, Pohlit AM, Pinto ACS, Silva ECC, Nogueira KL, Melo MRS, Henrique MC, Amorim RCN, Silva LFR, Costa MRF, Nunomura RCS, Nunomura SM, Alecrim WD, Alecrim MGC, Chaves FCM, Vieira PPR 2007. In vitro inhibition of Plasmodium falciparum by substances isolated from Amazonian antimalarial plants. Mem Inst Oswaldo Cruz 102: 359-365.

de Mesquita ML, Grellier P, Mambu L, de Paula JE, Espindola LS 2007. In vitro antiplasmodial activity of Brazilian Cerrado plants used as traditional remedies. J Ethnopharmacol 110: 165-170.

Diniz MA, Martins ES, Gomes E, Silva O 2000. Contribuição para o conhecimento de plantas medicinais da Guiné-Bissau. Portugaliae Acta Biol 19: 417-427.

Diniz MA, Martins ES, Silva O, Gomes ET 2008. Diversidade dos recursos vegetais na medicina tradicional da Guiné-Bissau. In Workshop Plantas Medicinais e Fitoterapêuticas nos Trópicos, Guiné-Bissau, 10 pp.

Dolabela MF, Oliveira SG, Nascimento JM, Peres JM, Wagner H, Póvoa MM, Oliveira AB 2008. In vitro antiplasmodial activity of extract and constituents from Esenbeckia febrifuga, a plant traditionally used to treat malaria in the Brazilian Amazon. Phytomedicine 15: 367-372.

Elufioye TO, Agbedahunsi JM 2004. Antimalarial activities of Tithonia diversifolia (Asteraceae) and Crossopteryx febrifuga (Rubiaceae) on mice in vivo. J Ethnopharmacol 93: 167-171.

Etkins NL 1988. Traditional medicine and traditional diseases: a framework for the evaluation of Hausa herbal pharmacopoeia. In Proceedings of Nigerian Society of Pharmacognosy Scientific Conference, Zaria, p. 9-15.

Etkins NL, Ross P 1982. Food as medicine and medicine as food: an adaptive framework for the interpretation of plant utilization among the Hausa of northern Nigeria. Soc Sci Med 16: 1559-1573.

Federici E, Palazzino G, Nicoletti M, Galeffi C 2000. Antiplasmodial activity of the alkaloids of Peschiera fuchsiaefolia. Planta Med 66: 93-95.

Gansané A, Sanon S, Ouattara LP, Traoré A, Hutter S, Ollivier E, Azas N, Traore AS, Guissou IP, Sirima SB, Nebié I 2010. Antiplasmodial activity and toxicity of crude extracts from alternatives parts of plants widely used for the treatment of malaria in Burkina Faso: contribution for their preservation. Parasitol Res 106: 335-340.

Garavito G, Rincón J, Arteaga L, Hata Y, Bourdy G, Gimenez A, Pinzón R, Deharo E 2006. Antimalarial activity of some Colombian medicinal plants. J Ethnopharmacol 107: 460-462. 
Goffin E, Ziemons De mol P, De Madureira MD, Martins AP, Da Cunha AP, Philippe G, Tits M, Angenot L, Fredrich M 2002. In vitro antiplasmodial activity of Tithonia diversifolia and identification of its main active constituent: Tagitinin C. Planta Med 68: 543-545.

Gomes AR, Vasconcelos T, de Almeida MHG 2008. Plantas na medicina tradicional de Cabo Verde. In Workshop Plantas Medicinais e Fitoterapêuticas nos Trópicos, Instituto de Investigação Científica Tropical/Centro Científico e Cultural de Macau, Macau, 13 pp.

Gomes ET, Silva O, Diniz MA, Martins ES 2003. Plantas medicinais da Guiné Bissau, Manual prático, ACEP/AD, Bissau, 78 pp.

Hellgren U, Johansson I, Dias F, Ericsson O, Stenbeck J, Rombo L 1991. Chloroquine resistant Plasmodium falciparum malaria in Guinea-Bissau. Trans R Soc Trop Med Hyg 85: 36.

Innocent E, Moshi MJ, Masimba PJ, Mbwambo ZH, Kapingu MC, Kamuhabwa A 2009. Screening of traditionally used plants for in vivo antimalarial activity in mice. Afr J Trad Complement Altern Med 6: 163-167.

Iwalewa EO, Omisore NO, Adewunmi CO, Gbolade AA, Ademowo OG, Nneji C, Agboola OI, Daniyan OM 2008. Anti-protozoan activities of Harungana madagascariensis stem bark extract on trichomonads and malaria. J Ethnopharmacol 117: 507-511.

Iwalokun BA 2008. Enhanced antimalarial effects of chloroquine by aqueous Vernonia amygdalina leaf extract in mice infected with chloroquine resistant and sensitive Plasmodium berghei strains. Afr Health Sci 8: 25-35.

Jaenson TG, Gomes MJ, Barreto dos Santos RC, Petrarca V, Fortini D, Evora J, Crato J 1994. Control of endophagic Anopheles mosquitoes and human malaria in Guinea Bissau, West Africa by permethrintreated bed nets. Trans R Soc Trop Med Hyg 88: 620-624.

Jansen PCM, Mendes O 1990. Plantas medicinais. Seu uso tradicional em Moçambique, Instituto Nacional do Livro e do Disco, Maputo, Tomo 3, $302 \mathrm{pp}$.

Jansen PCM, Mendes O 1991. Plantas Medicinais. Seu uso tradicional em Moçambique, Gabinete de Estudo da Medicina Tradicional, Maputo, Tomo 4, 299 pp.

Jurg A, Tomás T, Pividal J 1991. Antimalarial activity of some plant remedies in use in Marracuene, southern Mozambique. J Ethnopharmacol 33: 79-83.

Kager PA 2002. Malaria control: constraints and opportunities. Trop Med Int Health 7: 1042-1046.

Kambu K 1990. Eléments de phytothérapie comparée. Plantes médicinales africaines, Centre de Recherche Pédagogique, Kinshasa, $106 \mathrm{pp}$.

Kaur K, Jain M, Kaur T, Jain R 2009. Antimalarials from nature. Bioorg Med Chem 17: 3229-3256.

Khalid SA, Farouk A, Geary TG, Jensen JB 1986. Potential antimalarial candidates from African plants: an in vitro approach using Plasmodium falciparum. J Ethnopharmacol 15: 201-209.

Kirby GC, Paine A 1995. In vitro and in vivo antimalarial activity of cryptolepine, a plant-derived indoloquinoline. Phytother Res 9: $359-363$.

Kofoed PE, Lopez F, Johansson P, Sandström A, Hedegaard K, Aaby P, Rombo L 2002. Treatment of children with Plasmodium falciparum malaria with chloroquine in Guinea-Bissau. Am J Trop Med Hyg 67: 28-31.

Kolawole OM, Adesoye AA 2010. Evaluation of the antimalarial activity of Bridelia ferruginea benth bark. Can J Pure Appl Sci 4: 1039-1044.
Koumaglo K, Gbeassor M, Nikabu O, de Souza C, Werner W 1992. Effects of three compounds extracted from Morinda lucida on Plasmodium falciparum. Planta Med 58: 533-553.

Kraft C, Jenett-Siems K, Siems K, Gupta MP, Bienzle U, Eich E 2000. Antiplasmodial activity of isoflavones from Andira inermis. J Ethnopharmacol 73: 131-135.

Krettli AU, Andrade-Neto VF, Brandão MGL, Ferrari WMS 2001. The search for new antimalarial drugs from plants used to treat fever and malaria or plants ramdomly selected: a review. Mem Inst Oswaldo Cruz 96: 1033-1042.

Leaman DJ, Arnason JT, Yusuf R, Sangat-Roemantyo H, Soedjito H, Angerhofer CK, Pezzuto JM 1995. Malaria remedies of the Kenyah of the Apo Kayan, East Kalimantan, Indonesian Borneo: a quantitative assessment of local consensus as an indicator of biological efficacy. J Ethnopharmacol 49: 1-16.

Lenta BN, Ngouela S, Boyom FF, Tantangmo Tchouya GRF, Tsamo E, Gut J, Rosenthal PJ, Connolly JD 2007. Anti-plasmodial activity of some constituents of the root bark of Harungana madagascariensis LAM, (Hypericaceae). Chem Pharm Bull 55: 464-467.

Lopes D, Nogueira F, Gil JP, Ferreira C, do Rosário VE, Cravo P 2002. pfcrt and pfmdrl mutations and chloroquine resistance in Plasmodium falciparum from São Tomé and Príncipe, West Africa. Ann Trop Med Parasitol 96: 831-834.

Lopes NP, Kato MJ, Andrade EHA, Maia JGS, Yoshida M, Planchart AR, Katzin AL 1999. Antimalarial use of volatile oil from leaves of Virola surinamensis (Rol.) Warb. by Waiãpi Amazon Indians. J Ethnopharmacol 67: 313-319.

Loureiro LF, Cesário AM, Franco AS, Rosário VE 1996. Malaria in São Tomé and Príncipe: prevalence and drug-susceptibility. Ann Trop Med Parasitol 90: 223-224.

Mabunda SJA 2006. The epidemiology and the burden of malaria in Mozambique, PhD Thesis, Universitat de Barcelona, Barcelona, $221 \mathrm{pp}$.

MacKinnon S, Durst T, Arnason JT 1997. Antimalarial activity of tropical meliaceae extracts and gedunin derivatives. J Nat Prod 60: 336-341.

Madureira MC 2008. Investigação de plantas medicinais antimaláricas usadas na medicina tradicional de S. Tomé e Príncipe, In Workshop Plantas Medicinais e Fitoterapêuticas nos Trópicos, Macau, 28 pp.

Madureira MC, Martins AP, Gomes M, Paiva J, Cunha AP, Rosario VD 2002a. Antimalarial activity of medicinal plants used in traditional medicine in S. Tome and Principe islands. J Ethnopharmacol 81: 23-29.

Madureira MC, Martins AP, Paiva J, Proença da Cunha A 2002b. Medicinal plants and traditional medicine in the Gulf of Guinea - S. Tomé and Principe Islands, vol. VIII, Recent progress in medicinal plants, Researchco Book Centre, New Delhi, p. 361-381.

Maiga A, Malterud KE, Diallo D, Paulsen BS 2006. Antioxidant and 15-lipoxygenase inhibitory activities of the Malian medicinal plants Diospyros abyssinica (Hiern) F. White (Ebenaceae), Lannea velutina A. Rich (Anacardiaceae) and Crossopteryx febrifuga (Afzel) Benth. (Rubiaceae). J Ethnopharmacol 104: 132-137.

Mariath IR, Falcão HS, Barbosa-Filho JM, Sousa LCF, Tomaz ACA, Batista LM, Diniz MFFM, Athayde-Filho PF, Tavares JF, Silva MS, Cunha EVL 2009. Plants of the American continent with antimalarial activity. Rev Bras Farmacogn 19: 158-192.

Martet G, Da Conceicao S, Cordoliani G, Delolme H, Raphenon G, Hovette P, Doury JC, Baudon D, Touze JE, Lecamus JL 1991. 
Malaria in the republic of São Tomé and Principe. Epidemiologic evaluation and chemoresistance of P. falciparum. Bull Soc Pathol Exot 84: 273-280.

Masaba SC 2000. The antimalarial activity of Vernonia amygdalina Del (Compositae). Trans Roy Soc Trop Med Hyg 94: 694-695.

Mayor AG, Gomez-Olive X, Aponte JJ, Casimiro S, Mabunda S, Dgedge M 2001. Prevalence of the K76T mutation in the putative Plasmodium falciparum chloroquine resistance transporter ( $p f c r t$ ) gene and its relation to chloroquine resistance in Mozambique. J Infect Dis 183: 1413-1416.

Menegon M, Pearce RJ, Inojosa WO, Pisani V, Abel PM, Matondo A, Bisoffi Z, Majori G, Ord R, Warhurst DC, Roper C, Severini C 2009. Monitoring for multidrug-resistant Plasmodium falciparum isolates and analysis of pyrimethamine resistance evolution in Uíge province, Angola. Trop Med Int Health 14: 1251-1257.

MH - Ministry of Health 2003. National Malaria Control Programme, Ministry of Health, Maputo.

Millán-Orozco L, Corredoira E, San José MC 2011. In vitro rhizogenesis: histoanatomy of Cedrela odorata (Meliaceae) microcuttings. Rev Biol Trop 59: 447-453.

Milliken W 1997. Traditional anti-malarial medicine in Roraima, Brazil. Economic Botany 51: 212-237.

Moronkola DO, Ogunwande IA, Walker TM, Setzer WN, Oyewole IO 2007. Identification of the main volatile compounds in the leaf and flower of Tithonia diversifolia (Hemsl) Gray. J Nat Med 61: 63-66.

Newman DJ 2008. Natural products as leads to potential drugs: an old process or the new hope for drug discovery? $J$ Med Chem 51: 2589-2599.

Newman DJ, Cragg GM, Snader KM 2003. Natural products as sources of new drugs over the period 1981-2002. J Nat Prod 66: 1022-1037.

Noamesi BK, Paine A, Kirby GC, Warhurst DC, Phillipson JD 1991. In vitro antimalarial activity of cryptolepine, an indoquinoline. Trans R Soc Trop Med Hyg 85: 315.

Noedl H, Se Y, Schaecher K, Smith BL, Socheat D, Fukuda MM 2008. Evidence of artemisinin-resistant malaria in western Cambodia. N Engl J Med 359: 2619-2620.

Obih PO, Makinde M, Laoye OY 1985. Investigation of various extracts of Morinda lucida for antimalarial action on Plasmodium berghei berghei in mice. Afr J Med Med Sci 14: 45-50.

Oliveira AB, Dolabela MF, Braga FC, Jácome RLRP, Varotti FP, Póvoa MM 2009. Plant-derived antimalarial agents: new leads and efficient phythomedicines. Part I. Alkaloids. An Acad Bras Cienc 81: 715-740.

Oliveira FQ, Andrade-Neto V, Kretlli AU, Brandão MGL 2004. New evidences of antimalarial activity of Bidens pilosa roots extract correlated with polyacetylene and flavonoids. J Ethnopharmacol 93: 39-42.

Oliveira FQ, Junqueira RG, Stehmann JR, Brandão MGL 2003. Potencial das plantas medicinais como fonte de novos antimaláricos: espécies indicadas na bibliografia etnomédica brasileira. Rev Bras Plantas Med 5: 23-31.

Omer S, Zhang J, MacKinnon S, Leaman D, Durst T, Philogene BJR, Arnason JT, Sanchez-Vindas PE, Poveda L, Tamez PA, Pezzuto JM 2003. Traditionally used antimalarials from the Meliaceae. Curr Top Med Chem 3: 133-139.

Onyeibor O, Croft SL, Dodson HI, Feiz-Haddad M, Kendrick H, Millington NJ, Parapini S, Phillips RM, Seville S, Shnyder SD, Taramelli D, Wright CW 2005. Synthesis of some cryptolepine analogues, assessment of their antimalarial and cytotoxic activities and consideration of their antimalarial mode of action. $J$ Med Chem 48: 2701-2709.
Ortet R, Prado S, Mouray E, Thomas OP 2008. Sesquiterpene lactones from the endemic Cape Verdean Artemisia gorgonum. Phytochemistry 69: 2961-2965.

Ortet R, Thomas OP, Regalado EL, Pino JA, Filippi JJ, Fernández MD 2010. Composition and biological properties of the volatile oil of Artemisia gorgonum Webb. Chem Biodivers 7: 1325-1332.

Owoyele VB, Wuraola CO, Soladoye AO, Olaleye SB 2004. Studies on the anti-inflammatory and analgesic properties of Tithonia diversifolia leaf extract. J Ethnopharmacol 90: 317-321.

Paulo A, Gomes ET, Steele J, Warhurst DC, Houghton PJ 2000. Antiplasmodial activity of Cryptolepis sanguinolenta alkaloids from leaves and roots. Planta Med 66: 30-34.

Phillipson JD, Wright CW 1991. Can ethnopharmacology contribute to the development of antimalarial agents? J Ethnopharmacol 32: $155-65$.

Pinto J, Sousa CA, Gil V, Ferreira C, Gonçalves L, Lopes D, Petrarca V, Charlwood JD, do Rosário VE 2000a. Malária in São Tomé and Príncipe: parasite prevalences and vector densities. Acta Trop 76: 185-193.

Pinto J, Sousa CA, Gil V, Gonçalves L, Lopes D, do Rosário VE, Charlwood JD, 2000b. Mixed-species malaria infections in the human population of São Tomé island, West Africa. Trans $R$ Soc Trop Med Hyg 94: 256-257.

Presber W, Hegenscheid B, Hernandez-Alvarez H, Herrmann DK, Brendel C 1992. Inhibition of the growth of Plasmodium falciparum and Plasmodium berghei in vitro by an extract of Cochlospermum angolense (Welw.). Acta Trop 50: 331-338.

Ramalhete C, Lopes D, Mulhovo S, Molnár J, Rosário VE, Ferreira MJU 2010. New antimalarials with a triterpenic scaffold from Momordica balsamina. Bioorg Med Chem 18: 5254-5260.

Ramalhete C, Lopes D, Mulhovo S, Rosário VE, Ferreira MJU 2008. Antimalarial activity of some plants traditionally used in Mozambique. In Workshop Plantas Medicinais e Fitoterapêuticas nos Trópicos. Available from: 2.iict.pt/archive/doc/C_Ramalhete_wrkshp_plts_medic.pdf.

Riel MA, Kyle DE, Milhous WK 2002. Efficacy of scopadulcic acid A against Plasmodium falciparum in Vitro. J Nat Prod 65: 614-615.

Rodrigues A, Schellenberg JA, Kofoed PE, Aaby P, Greenwood B 2008. Changing pattern of malaria in Bissau, Guinea Bissau. Trop Med Int Health 13: 410-417.

Roersch CMFB 2010. Piper umbellatum L.: a comparative cross-cultural analysis of its medicinal uses and an ethnopharmacological evaluation. J Ethnopharmacol 131: 522-537.

Roseira L 2004. Plantas úteis da flora de S. Tomé e Príncipe, medicinais, industriais e ornamentais, Grafica 2000, Lisboa, 21 pp.

Sanon S, Ollivier E, Azas N, Mahiou V, Gasquet M, Ouattara CT, Nebie I, Traore AS, Esposito F, Balansard TDP, Fumoux F 2003. Ethnobotanical survey and in vitro antiplasmodial activity of plants used in traditional medicine in Burkina Faso. J Ethnopharmacol 86: 143-147.

Sequeira V 1994. Medicinal plants and conservation in S. Tomé. Biodiversity Conserv 3: 910-926.

Steele JCP, Simmonds MSJ, Veitch NC, Warhurst DC 1999. Evaluation of the anti-plasmodial activity of bisbenzylisoquinoline alkaloids from Abuta grandifolia. Planta Med 65: 413-416.

Steele JCP, Veitch NC, Kite GC, Simmonds MSJ, Warhurst DC 2002. Indole and carboline alkaloids from Geissospermum sericeum. J Nat Prod 65: 85-88.

Teklehaimanot HD, Teklehaimanot A, Kiszewski A, Rampao HS, Sachs JD 2009. Malaria in São Tomé and Príncipe: on the brink of elimination after three years of effective antimalarial measures. Am J Trop Med Hyg 80: 133-140. 
Tona L, Cimanga RK, Mesia K, Musuamba CT, De Bruyne T, Apers S, Hernans N, Van Miert S, Pieters L, Totté J, Vlietinck AJ 2004. In vitro antiplasmodial activity of extracts and fractions from seven medicinal plants used in the Democratic Republic of Congo. J Ethnopharmacol 93: 27-32.

Tona L, Ngimbi NP, Tsakala M, Mesia K, Cimanga K, Apers S, De Bruyne T, Pieters L, Totté J, Vlietinck AJ 1999. Antimalarial activity of 20 crude extracts from nine African medicinal plants used in Kinshasa, Congo. J Ethnopharmacol 68: 193-203.

Turschner S, Efferth T 2009. Drug resistance in Plasmodium: natural products in the fight against malaria. Mini Rev Med Chem 9: 206-2124

Uchôa VT, Paula RC, Krettli LG, Santana AEG, Kretti AU 2010. Antimalarial activity of compounds and mixed fractions of $\mathrm{Ce}$ cropia pachystachya. Drug Dev Res 71: 82-91.

Ukwe VC, Epueke EA, Ekwunife OI, Okoye TC, Akudor GC, Ubaka CM 2010. Antimalarial activity of aqueous extract and fractions of leaves of Ageratum conyzoides in mice infected with Plasmodium berghei. Int J Pharm Sci 2: 33-38.

Ursing J, Kofoed PE, Rodrigues A, Rombo L, Gil JP 2007. Plasmodium falciparum genotypes associated with chloroquine and amodiaquine resistance in Guinea-Bissau. Am J Trop Med Hyg 76: 844-848.

USAID - United States Agency for International Development 2009. Mozambique Country Strategic Plan 2004-2010. Available from: usaid.gov/mz/health.htm.

Van-Dúnem MB 1994. Plantas medicinais de Angola: medicamentos ao alcance de todos, 1st ed., Cooperação Portuguesa/Embaixada de Portugal, Luanda, $78 \mathrm{pp}$.

van Wyk BE, Oudtshoorn B, Gericke N 1997. Medicinal plants of South Africa, Briza Publications, Pretoria, 304 pp.

Verpoorte R, Kim HK, Choi YH 2006. Plants as source of medicines. In RJ Bogers, LE Craker, D Lange, Medicinal and aromatic plants, Springer, Netherlands, p. 261-273.
Verzar R, Petri G 1987. Medicinal-plants in Mozambique and their popular use. J Ethnopharmacol 19: 67-80.

WCMC - World Conservation Monitoring Centre 1992. Global biodiversity status of the earth's living resources, Chapman \& Hall, London, $614 \mathrm{pp}$.

WHO - World Health Organization 2005. Communicable Disease Toolkit for Angola, Available from: whqlibdoc.who.int/hq/2005/ WHO_CDS_NTD_DCE_2005a_profile.pdf.

WHO - World Health Organization 2006. Guidelines for the treatment of malaria. Document WHO/HTM/MAL/2006.1108. Available from: whqlibdoc.who.int/publications/2006/9241546948_eng.pdf.

WHO - World Health Organization 2008. Guinea-Bissau. Available from: who.int/malaria/publications/country-profiles/profile_gnb_ en.pdf.

WHO - World Health Organization 2009a. World Malaria Report 2009. Available from: who.int/malaria/world_malaria report_2009/en/index.html.

WHO - World Health Organization 2009b. Available from: who.int/ malaria/publications/country-profiles/profile_moz_en.pdf.

WHO - World Health Organization 2010. World Malaria Report 2010. Available from: who.int/malaria/world_malaria_report_2010/ en/index.html.

WHO - World Health Organization 2011. Malaria in Cape Verde. Available from: who.int/countries/cpv/areas/malaria/en/index.html.

Wright CW, Addae-Kyereme J, Breen AG, Brown JE, Cox MF, Croft SL, Gökçek Y, Kendrick H, Phillips RM, Pollet PL 2001. Synthesis and evaluation of cryptolepine analogues for their potential as new antimalarial agents. $J$ Med Chem 44: 3187-3194.

Wright CW, Phillipson JD, Awe SO, Kirby GC, Warhurst DC, QuertinLeclerq J, Angenot L 1996. Antimalarial activity of cryptolepine and some other anhydronium bases. Phytother Res 10: 361-363. 